\title{
APPLICATION OF REVITALISANTS FOR EXTENSION OF RESOURCE AND RESTORING WORN-OUT FRICTION UNITS OF AVIATION AXIAL - PISTON HYDROMACHINES
}

\author{
V. Babak, V. Stadnychenko
}

National Aviation University, Kyiv, Ukraine.E-mail: stadnichenko_kiev@hotmail.com Received 2002 2004; accepted 26022004

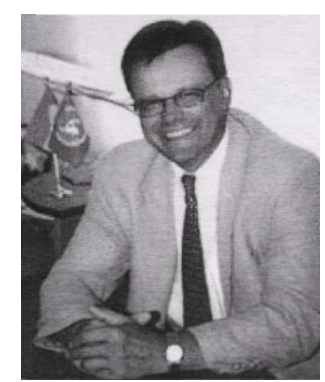

Vitalii BABAK, $\mathrm{PhD}$

Date and place of birth: 1954, Lubny, Ukraine

Education: Kiev Polytechnic Institute

Affiliation and functions: Rector of National aviation university since 1998, $1995-\mathrm{PhD}$ from Polytechnic Institute Research interests: diagnostics of technological process, laser and computer modeling and manufacturing, automatic diagnostics systems.

Publications: over 250 articles and monographers

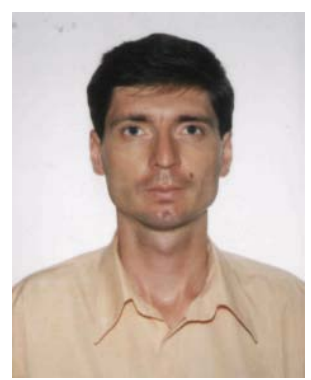

Viatcheslav STADNYCHENKO, CtS

Date and place of birth: 1971, Ungeny, Moldova

Kharkiv military aviation engineering school

Affiliation and functions: assistant professor of National aviation university since 2003, 1997 - candidate of technical science from NSRI "HYDROPRIVOD"

Research interests: friction and wear diagnostics of technological process, automatic diagnostics systems

Publications: over 15 articles and monographers

Abstract. The perspectives of application of using RVS technique for repairing and prophylactic of hydraulic systems' units, particularly axial-piston machines are considered. Physical background of revitalization processes, which took place on the friction surfaces during drifting of cermets coating (CC) are uncovered. The results were received from numerous investiga-tions.

Keywords: friction and wear, trybology, resource, revitalizant, RVS technique, acoustic emission, automized system, tribo diagnostics (AST).

\section{Introduction}

The repair of friction units without disassembly and deduction of an aggregate from maintenance have received a wide circulation recently. Besides, the new units are exposed to the same treatment for wear prevention and extension of their resource. It is possible to term all products for similar treatment as revitalizants that are the substances, which regenerate the life of a friction pair. At the first occurrence in the modern market, this technique was termed as RVS. So the developers on abbreviation called it from "repair reconstruction composition (in Russian)". This composition has appeared in depths of the defensive complex of the Soviet Union in the beginning of 80th years of the last century.

The modern conditions of the Ukrainian market of products, which can be referred to revitalizants, are characterized by an abundance of the trade marks ("AB",
"Venom", "Remit", "RVS", "Chador", "Energy Release", "Forum" and etc) and wide geography of the producers (USA, Byelorussia, Russia, Ukraine and etc.). But in all variety of the information it is impossible to discover though any scientific grounds of operation of similar compositions. All producers are restricted to the recommendations in the basic advertising and declarative character. It is explained by the commercial classified information, the protection of "knows how" etc., though in the most cases scientific data, most likely, primly miss. Thus each producer tries to term technique on a name of the product.

\section{Statement of the problem and the methodology of investigations}

Though availability of application of similar products for repair and prophylaxis of friction pairs of hydraulic systems' units is obvious, RVS technique is not 
spreaded in hydraulics so promptly, as, for example on motor or railway transport. Thus the analysis of wears of the friction pairs of volumetric hydro machines testifies that their resource appreciably depends on reliability of pairs "distributive slide - rotor end", "bush - piston" and "thrust button - chock". [6,2]. The investigation, carried out by us, display, that the mode of operations of these pairs quite allows to apply revitalizants for the extension of their resource. Besides, in such situation it is possible to proceed to the manufacture of chock from steel or cast iron that will reduce the production of manufacture of these units. Besides all producers of revitalizants recommend treating the bearings that are presented in a construction of hydro pumps using RVS technique. And the results of RVS application for repair ICE [4] allow to forecast the success of this technique under repair of friction pair "bush-piston", because the requirements of its operation are similar to the operation of a pair "bush sleeve - ring".

The authors, having analyzed accessible radiants about compositions of all similar products, have made an output about their similarity. A basis of the majority from them is the complexes of fine natural minerals of the ultra basic breeds with adding of catalytic agents. For investigations, the composition with the optimized properties due to the heightened content of oxides of aluminum and silicon designed. More complete information about the composition of product cannot be published up to a termination of procedure of licensing. Thus we are inclined to term this technique traditionally: RVS technique. The investigations of the selected composition were carried out and the regularities of a common pattern of formation, existence on a surface and protective actions of cermets coating (CC) are detected.

Complexity and specificity of a delivered problem asked the creation of the automized system of tribodiagnostics (AST), permitting to control the reproportioning of tested pairs during the experiment, and also to evaluate the character of processes, flowing past at it. The first purpose was reached with the help of the electromechanical device of registration of the reproportioning of tested pairs (EDRRTP) that was included in system. Its construction and principle of an operation explicitly are explained in the work [4]. The second purpose was achieved with the help of an acoustic emission method. A construction and principle of an operation of this part of atomized system of tribe diagnostics are circumscribed in the work [3].

The tests were carried out on samples, at the procedure and under the requirements that are explained in full $[4,3]$. The results of recording of width of a generatrix coating are submitted in figure 1. All series of tests were carried out with a stopping after 8 hour of tests for 12-16 hours. The common time of experiment made 80 hours. In time 5-7 hours after leading of the revitalizant in lubrication the growth of the coating has stopped and further remained at this level up to the end of tests.

The upper bound of width of a film registered on a recorder $\mathrm{H} 307$ made $0,020-0,025 \mathrm{~mm}$. The further measuring of the increase of samples' mass in view of density of the generatrix coating has shown, that the actual width on all friction surfaces does not exceed $0,003-0,005 \mathrm{~mm}$. It is possible, that under other requirements the restoring of more considerable width of the unit can exist, but it will be shown by the further tests.

In any case, it is easy to explain failures of the majority of the independent researches, who did not detect the positive effect promised by the manufactures of RVS compositions over the absence of the similar AST at their order, and also poor time of holding tests.

\section{The results of investigations and their explanation}

You see that the only the visual every second information about trybology processes happening on the friction surfaces can allow to clear up such composite effect, as the formation and operation protective $\mathrm{CC}$ coating obtained from revitalizant with the help of RVS technique. EDRRTP and complex AE included in our AST give such information.

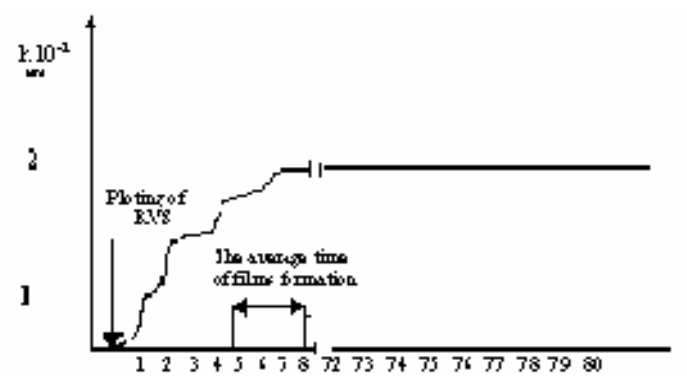

Fig 1. The dynamics of coating width's growth in the contact zone

For an explanation of a disparity between recoded and actual width the conjecture was put forward which has found the affirming during the further tests and metallophysics examinations. Axle of the formed film appears on friction surfaces at ploy CC coating. It as if is squeezed out at friction before a platform of contact owing to high pressure and considerable ductility of coating.

Being fractionally tightened in the contact zone, this heavy CC stratum of a deformed film is also registered by EDRRTP, giving us the a little bit garbled observations. In it, thick enough, separating stratum also the dissipation of input exterior mechanical energy in thermal take place. The microphotographing of surfaces after treatment has shown presence of similar beads on them (figure 2). Thus, we fixed instantaneous width of the coating in the zone of immediate contact distinguished from medial width of coating on all surface.

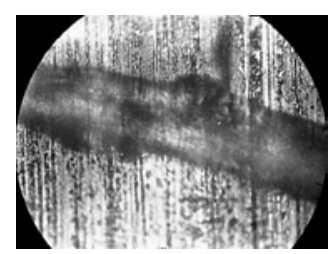

Fig 2. The bulge of coating in front of the contact zone $(\times 290)$ 
At recording of $\mathrm{AE}$ parameters on the shield of an oscillograph the signals shown in the places of the histogram, relevant to them, were observed in figure 3. Before leading of RVS in lubrication and at the first hour after that the signal on the shield was referenced for processes of normal outwearing. However in accordance with formation of the coating, the signal was augmented and got the form that is typical for processes of frictional seizure: the amplitude was augmented by 2-3 order, and the base line of a signal after a reference fracture stopped at the other level.

And in the final period of tests (on the average between $40^{\text {th }}$ and $50^{\text {th }}$ hours) the signal of acoustic emission disappeared, that is the friction pair creased to be outworn.

The diagram of an AE signal at quantization on a level registered on a recorder $\mathrm{H} 306$, had a corresponding amount of peaks, each of which corresponds to one gang of a quantum level: at more intensive acoustic emission we have more picks e for a time unit and on the contrary.

On width of the diagram of the gang of one quantum level the dynamic of surface processes for all cycle of tests is obviously visible. When the finally generated coating began to work in a condition "out-wear", the diagram of recording of spectral power of AE was drawn out in a line, parallel axes of time.

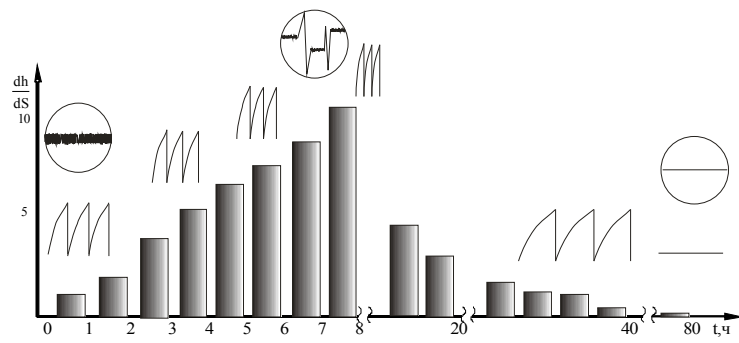

Fig 3. AE signal histogram for the all period of tests with cuts of the diagram and form of AE signal on the shield of an oscillograph

In figure 4 the results of measuring of weight wear of samples with plotted the coating are submitted. Weighing carried out after every of eight hours of experiment. The results have shown, that at the first day the weight wear had peak. In each consequent cycle of tests there was an inappreciable restoring of the worn out stratum. Approximately after 40 hours of tests the wear of samples was recovered completely and to the end of experiment the inappreciable increase of a mass of samples was fixed 1 (on the average about 0,002 grams).

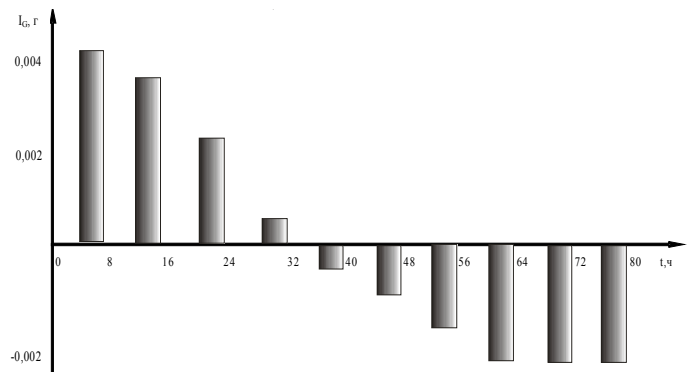

Fig 4. Histogram of samples' weight wears at time of caring of coating
Further the more deep metallophysics investigations were carried out. At the bottom of lubricated bath, in which the rollers were greased, the brilliant antimagnetic wear fragments were found that had tubular-spiral shape. The appearance of such debrises is shown in figure 5.

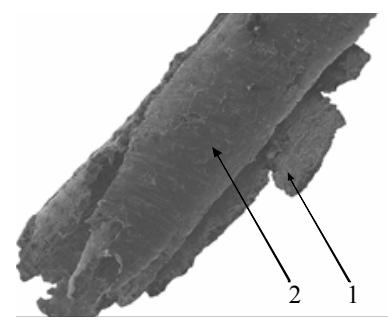

Fig 5. 1- inside wear fragment; 2- outside wear fragment $(\times 52)$

On a raster electronic microscope with the microanalyzer CAMSCAN fractal graphics and chemical analysis of inside and outside surfaces of this debris were carried out. These effects are shown in figure 6. As it is visible, the basic chemical element in a composition of this coating is the aluminum; silicon was the second by the percentage.

On the ground of these and some consequent researchers, the authors made outputs about the mechanism both physical substance of formation and operation of the coating, which was drifted on the friction surface using RVS - technique during operation, and also about the nature of a protective and regenerating operation of this coating.

The formation of this coating requires an application of a great amount of energy, as the drifting was carried out at specific pressure in contact $950 \mathrm{MPa}$. At lowering this magnitude the deceleration of a generation rate of a film was observed, and at $600 \mathrm{MPa}$ during all 80 hours of experiment the growth of the coating generally was not fixed.

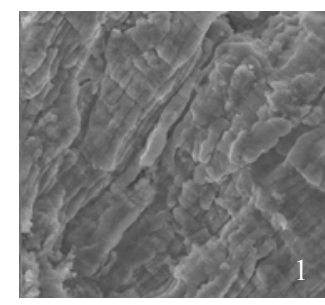

\begin{tabular}{|c|c|c|}
\hline Emt & Zaf & Atom, $\%$ \\
\hline $\mathrm{Al}$ & 1,293 & 91,951 \\
$\mathrm{~S}$ & 0,898 & 5,658 \\
$\mathrm{Fe}$ & 0,584 & 1,001 \\
$\mathrm{Co}$ & 0,848 & 0,000 \\
$\mathrm{Cu}$ & 0,824 & 1,390 \\
\hline Total & - & 100,000 \\
\hline
\end{tabular}

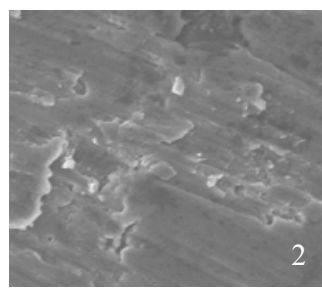

\begin{tabular}{|c|c|c|}
\hline Emt & Zaf & Atom, $\%$ \\
\hline $\mathrm{Al}$ & 1,185 & 95,747 \\
$\mathrm{~S}$ & 0,377 & 2,943 \\
$\mathrm{Fe}$ & 0,854 & 0,548 \\
$\mathrm{Co}$ & 0,841 & 0,000 \\
$\mathrm{Cu}$ & 0,823 & 0,762 \\
\hline Total & - & 100,000 \\
\hline
\end{tabular}

Fig 6. 1- inside friction fragment; 2- outside friction fragment $(\times 1000)$

At the first minutes after leading RVS composition in lubrication there is density of its fragments on a surface in the sufficient amount to course of reaction. Then reaction begins, as a result of which the separate sports covered with film of an oxide of aluminum with inserts of 
silicon appear on friction surfaces. It is in an amorphous condition and has a very high adhesive power. There of, in the contact to the surface, which has been not covered with this substance yet, there is an abruption of most thin films of secondary structures (SS) from the surface of metal. Thus, there is a removal of all defect high layers of samples. Simultaneously with "ablution" from microimperfections, there is an activation of the surface of metal. The process of accumulation of enough fissile components of a composition and activation of friction surfaces explains an undulating aspect of the diagram of growth of the coating (figure 1).

The processes frictional seizure of viscous films with a consequent separation them together with a high layer of the surface are explained by a reference aspect of AE signal in this continuance, and also its accelerated intensity at the first 5-8 hours (figure 3). The same processes explain the presence in lubrication after the first stage of drawing of specific wear fragments, which exposed to the profound investigation. Surfaces of samples at this stage have the reference appearance: at photographing with 290-multiple magnification on them the places of abruption of separate sites of a high layer (figure 7) are visible.

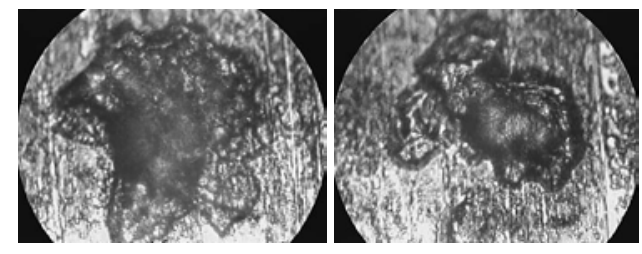

Fig7. Surface appearance in the initial stage of coating precipitation $(\times 290)$

The lowering in consequent of intensities of acoustic emission, restoring of the worn out stratum and transition to practically out-wear friction is explained by the further transformation of the coating. An oxide of silicon and friction fragments of the basic material reinforces the viscous matrix of an oxide of aluminum. Thus, the coating acquires properties of a composition material. The adhesive power of a film is reduced, frictional seize is stopped. It is visible on a level of AE signal (figure 2).

The structure of the formed coating has the sandwich- globular structure (figure 6-1). It allows the surface, having ability to supermovability, to srelaxate stress collecting in a high layer as a result of contact interaction at friction at the expense of reorientation of blocks of structure, isometric migration separate globulars, and also macrochift of all surfaces.

The reorientation of structural blocks at operation of RVS cofting is well visible in figure 8.

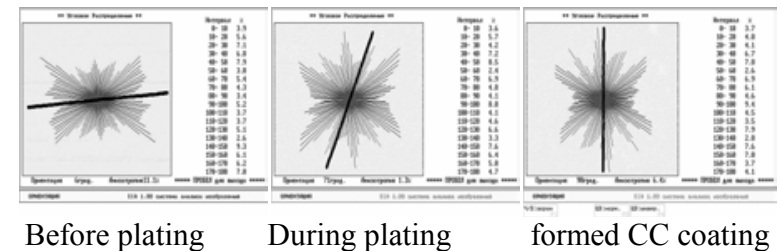

Fig 8. Orientation of blocs of CC coating structure concerning main operating strains
It shows the orientation of blocks of structure of $\mathrm{CC}$ coating concerning main operating strains obtained on the basis of the Fourier - analysis of anisotropy of structural components of friction surface with the help of the program SIA 1.00.

Before plating blocks are orientated on the direction of friction (horizontally). Such pattern is characteristic for the majority of usual friction pairs. But during drawing of $\mathrm{CC}$ stratum their reorientation get a direction, perpendicular the direction of friction. More probably that, the ability of specific structure of CC coating to isometric rotational displacement forces the surface to behave in a similar way. At similar orientation it is easier for globulars of structure to relaxate strains collecting in the surface, at the expense of isometric detrusion.

Besides, due to all set forth above features, the coating has property of an abnormal toughness and movabilities at enough high strength. It allows it during operation to realize macroshift migration on the sample's surface. These microshifts are well visible in photos made in different points of rollers in different instants after the coating forming was completed (figure 9). Similar properties "quasi-liquid stratum", originating on friction surfaces at presence fine natural minerals with adding of catalytic agents and its ability to create dynamic protective films were noted by the contributors of geomodifiers of friction (GMF) [4, 3]. GMF are a varietyof revitalizants. Their distinctive performance is the opportunity of restoring of friction units at the expense of initiation self-organizing triboprocess in a direction of restoring of physical links of surface stratum with fine medium of the basic material in lubricant medium [3,7]. The presence of likeness in the mechanism of operation different revitalizants allows speaking about detection of really common principles of their forming and operation.

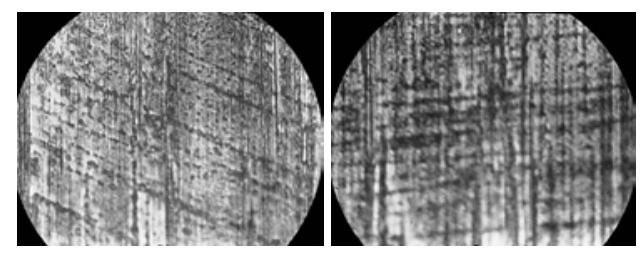

Fig 9. Photomicrography of friction surfaces after the end of plating $(\times 290)$

It is visible, that depending on the condition of coating, and also from a direction of an operation of axial component force of contact pressure, (it arises from a strain of shafts of the friction machines at a loading), the migration of surface can happen under different corners to the direction of friction, down to the perpendicularity to it. Which from mechanisms of relaxation of surface strains is principal at operation of CC coating platted using RVS technique, while it is impossible to answer uniquely. For this purpose the further examinations are required. It is possible, that both mechanisms exist parallel and their interaction and ensures practically wear-out condition of friction treated in a similar way pair.

It is necessary to search an explanation of the quaziout-wear behavior of $\mathrm{CC}$ stratum as contrasted to by 
behavior SS of usual friction pairs, on our opinion, in distinctions of rheological behavior of these thin-film plants in the contact field. In the first case it can be circumscribed with the help of Prandtl rheological model (figure $10 \mathrm{c}, \mathrm{d}$ ). The behavior classical BC is most precisely featured theological model of Kelvin - Foygt (figure 10, a, b) [5].
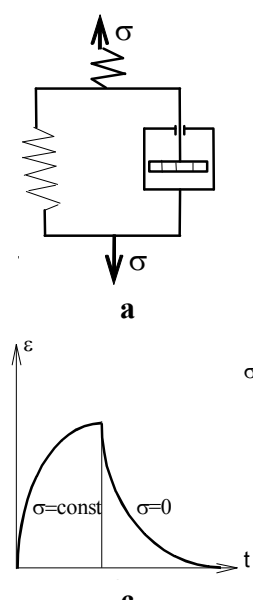

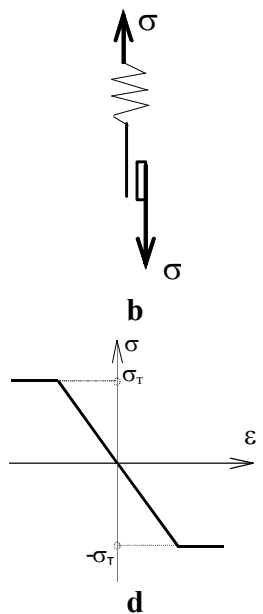

d
Fig 10. Rheological models (a, c) and rheological curves (в, г) Kelvin - Foygt and Prandtl

With its help the behavior of SS films is featured by a combination of solids of Hooke (ideal elasticity)

$\sigma=\varepsilon \mathrm{E}$

and Newton (viscous fluxion):

$\sigma=\eta \frac{\mathrm{dV}}{\mathrm{dz}}=\eta \frac{\mathrm{dx}}{\mathrm{dt} \cdot \mathrm{dz}}=\eta \frac{\mathrm{d} \varepsilon}{\mathrm{dt}}=\eta \varepsilon$

Here $\frac{d x}{d z}=d \varepsilon-$ Relative shear strain. Then

$$
\sigma=\sigma_{\mathrm{E}}+\sigma_{\eta}=\mathrm{E} \cdot \varepsilon+\eta \dot{\varepsilon}
$$

Assuming $\sigma=$ const and integrating, we obtain the law of strain development in time:

$$
\varepsilon=\left(\frac{\sigma}{E}\right)\left[1-\exp \left(-\frac{E}{\eta}\right) t\right]
$$

If in any instant $\tau$ to unload the solid $(\sigma)$, integrating the equation (1), we shall receive the law of lowering of strain in time:

$$
\varepsilon=\varepsilon_{\tau} \exp \left[\left(-\frac{E}{\eta}\right)(t-\tau)\right] .
$$

Ratio $\frac{E}{\eta}=\mathrm{t}_{0}$ term as a relaxation time.

And the model of Prandtl characterizes behavior of Bingham solids: $\left\{\begin{array}{l}\sigma=\mathrm{E} \varepsilon \text { at }-\varepsilon_{\mathrm{T}}<\varepsilon<\varepsilon_{\mathrm{T}} ; \\ \sigma=-\sigma_{\mathrm{T}} \operatorname{singn} \varepsilon \text { at }-\varepsilon_{\mathrm{T}} \geq \varepsilon \geq \varepsilon_{\mathrm{T}} .\end{array}\right.$
Here $\varepsilon$ - resiliency at $\sigma=\sigma_{\mathrm{T}}, \sigma_{\mathrm{T}}$ - yield point. When $\sigma$ $<\sigma_{\mathrm{T}}$, only Hook's solid is resilienced. When $\sigma \geq \sigma_{\mathrm{T}}$, resilience grows without limit because slippage of SenVenan's solid at constant resilience of springing element [5].

\section{Conclusions}

On the base of this rheology model further simulation of operation of the CC coating, in particular build-up its mathematical model are possible.

All aforesaid allows speaking about an opportunity to work out the concrete technological recommendations for application of RVS techniques for restoring and preventive measures of friction units of axial - piston hydro machines further.

\section{References}

1. Аратский П.Б., Капсаров А.Г. Применение геомодификаторов трения для увеличения ресурса работы металлообрабатывающего инструмента // Трение, износ, смазка. - 2001. - Т. 3, № 1.

2. Войтов В.А., Березняков А.И., Стадниченко В.Н. и др.. Влияние трибологических факторов на акустическое излучение фрикционных узлов объёмных гидромашин // Информационные технологии. Моделирование рабочих процессов в теплотехническом, энергетическом оборудовании и проблемы энергосбережения. - Харьков, Мишкольц, Магдебург, 1997. - Ч. 2. - С. 26-30.

3. Джус Р.М., Стадніченко В. М., Стадніченко М.Г. Пристрій для беззупиної реєстрації динаміки зміни геометрії зразків при випробуваннях на тертя i знос // Вестник Национального технического университета “ХПИ”. -2003. - Т.1, № 12 .

4. Еськов В.Е. ХАДО - это очень просто // Совершенно секретно. - 2001, №9.

5. Половинкин В.Н., Лянной В.Б., Аратский П.Б. Применение геомодификаторов трения для восстановления изношенных поверхностей узлов трения при эксплуатации // Трение, износ, мазка. 2000. - T. 2, № 2.

6. Стадниченко В.Н. Диагностирование технического состояния гидромашин в процессе эксплуатации // Межвузовский сборник научных трудов/ ХАРГАЖТ. - 1997. - Вып. 30. - С. 96-97.

7. Стадніченко В. М., Стадніченко М. Г., Джус Р. М., Чотій Л.Ю. Вибір інформативних параметрів акустичної емісії для структурної побудови автоматизованоїсистеми системи контролю процесів зношування. - Вопросы проектирования и производства конструкций летательных аппаратов // Сб. науч. тр. Нац. аэрокосмич. ун-та им. Н.Е. Жуковского «ХАИ». Харьков: НАКУ, 2003. - Вып. 34 (3). 